\title{
PERLAWANAN BAGUS RANGIN: PERANG NASIONAL YANG TERLUPAKAN
}

\author{
Oleh \\ Herni Purnaningsih dan Agus Mulyana ${ }^{1}$
}

\begin{abstract}
ABSTRAK
Artikel ini berjudul "Perlawanan Bagus Rangin: Perang Nasional yang Terlupakan”. Penelitian ini mengkaji mengenai perlawanan Bagus Rangin di Cirebon pada tahun 1806-1812. Masalah utama yang diangkat dalam skripsi ini adalah "Mengapa terjadi perlawanan Bagus Rangin dan bagaimana pengaruhnya terhadap masyarakat pada masa yang akan datang?". Metode yang digunakan adalah metode historis dengan melakukan empat langkah penelitian, yaitu heuristik, kritik, interpretasi, dan historiografi. Berdasarkan hasil penelitian dapat dijelaskan bahwa latar belakang terjadinya perlawanan Bagus Rangin tahun 1806-1812 ialah karena penerapan sistem pajak yang tinggi yang diterapkan pemerintah kolonial, eksploitasi yang dilakukan bangsa kolonial dan dominasi politik yang dilakukan pemerintah kolonial terhadap kesultanan Cirebon hingga menyebabkan berkurangnya peran sultan di keresidenan Cirebon. Perlawanan yang dilakukan rakyat Cirebon ini dipimpin oleh sosok pemimpin kharismatik yang bernama Bagus Rangin, pemimpin ini bersifat messiah karena dianggap sebagai ratu adil yang akan menyelamatkan masyarakat Cirebon dari kesewenangan kolonial Belanda. Dampak dari perlawanan ini yakni mengilhami dan memberikan semangat juang bagi generasi selanjutnya untuk melawan kolonialisme yang dilakukan bangsa asing.
\end{abstract}

Kata Kunci : Bagus Rangin, pemerintahan kolonial, keresidenan Cirebon.

\begin{abstract}
This article entitled "Bagus Rangin Resistance: The Forgotten National War". The main issue discussed in this essay is "Why there is resistance of Bagus Rangin in the year of 1806-1812 and how it affects society in the future". The problem is assesed using the historical method through four steps of activity, there are; heuristic, criticism, interpretation and historiography. The result showed that the background of the Bagus Rangin resistance in 1806-1812 are because the high tax system applied by the colonial government, colonial exploitation and political domination of the Sultante of Cirebon which cause a reduction in the role of the Sultan in Cirebon residency. The leader of this resistance movement was called Bagus Rangin, people assumed that he is the messiah that being perceived as 'Ratu Adil' who will save the people, especially farmers and students from colonial
\end{abstract}

\footnotetext{
${ }^{1}$ Penulis merupakan mahasiswa Jurusan Pendidikan Sejarah FPIPS UPI. Agus Mulyana sebagai pembimbing. Penulis dapat dihubungi melalui email chill_686@yahoo.com
} 
tyranny. The impact of Bagus Rangin resistance is giving inspiration for the people of Cirebon to fight colonialism.

Keywords: Bagus Rangin, colonial government, Cirebon residency.

\section{PENDAHULUAN}

Diakhir abad ke-18 VOC (Verenigde

Oost-Indische

Compagnie) mengalami kebangkrutan dan para pejabat VOC mulai merasakan bahwa kompeni tidak lagi memperoleh apa yang diharapkan. Masa kejatuhan VOC ini diambil alih oleh pemerintah Kerajaan Belanda, hingga awal abad ke-19 bisa dikatakan merupakan awal mula diterapkannya politik pemerintahan kolonial di Nusantara, khususnya Pulau Jawa. Dominasi barat tidak hanya terjadi pada bidang politik saja. Dalam bidang ekonomi, kolonial berusaha mengekspolitasi secara berkelanjutan dan terus menerus. Sehingga hal tersebut dapat mengancam jaring pengaman sosial mereka atas sumbersumber substensial. Penjajahan kolonial yang terjadi pada abad tersebut menyebabkan kondisi-kondisi yang mendorong rakyat untuk melakukan pergerakan sosial. Reaksi yang ditimbulkan ialah dengan melakukan gerakan sosial, yang semakin digerakan oleh ideologi mesianistik yang bermakna pengharapan akan datangnya Ratu Adil, gerakan tersebut dilakukan secara agresif dan radikal. Seperti halnya dalam buku Sejarah Nasional Indonesia IV karya Poesponegoro dan Notosusanto (1993) bahwa:

Sikap rakyat dalam mengambil bagian dalam gerakan-gerakan sangat radikal, karena digerakkan oleh harapanharapan yang ditimbulkan oleh ajaran-ajaran mesianistik atau milenaristik dan juga dengan pandangan eskatologi yang bersifat revolusioner (hal. 279).

Selama ini sejarah bangsa Indonesia mengenal perjuangan Pangeran Diponegoro sebagai sosok Ratu Adil dalam melawan penjajah. Perang yang berlangsung pada tahun 1825 - 1830 tersebut menjadi bagian yang tidak terpisahkan dari perjalanan bangsa Indonesia dalam menghapuskan kolonialisme di Indonesia. Namun tidak banyak orang yang tahu bahwa sebelum perang Diponegoro, telah terjadi perang hebat yaitu disebut dengan perang Cirebon 
yang terjadi di Jawa bagian Barat. Bahkan dahsyatnya perang Cirebon ini telah dibukukan dalam arsip Belanda, tulisan yang dibuat dengan gaya naratif-deskriptif ini ditulis oleh salah satu pimpinan Belanda yang bernama Van Der Kemp dan telah diterjemahkan kedalam bahasa Indonesia ejaan lama pada tahun 1952.

Perang Cirebon terjadi pada permulaan tahun 1800-an dan merupakan cikal bakal terjadinya serentetan peristiwa perlawanan rakyat Cirebon selama beberapa tahun kemudian. Salah satu tokoh kharismatik yang menjadi pelopor perlawanan Cirebon pada saat itu adalah Bagus Rangin, kehidupan beliau yang berlatarbelakang agamis menyebabkan ia menjadi tokoh yang disegani yang mampu mengumpulkan banyak massa, sehingga wajar jika masyarakat menganggapnya sebagai Ratu Adil. Ketidakpuasan rakyat Cirebon khususnya para petani pada saat itu mendesak Bagus Rangin untuk segera melakukan perlawanan terhadap pemerintah kolonial. Perlawanan tidak hanya ditujukan terhadap pihak kolonial melainkan juga terhadap etnis Cina yang dianggap sebagai antek-antek

kolonial.

Cirebon merupakan daerah keresidenan yang meliputi regentschap Cirebon, Kuningan, Majalengka dan Indramayu. Cirebon terdiri dari 3 kesultanan, yaitu Sultan Sepuh (Kasepuhan), Sultan Anom (Kanoman), dan Sultan Cirebon (Kacirebonan). Pada awal abad ke-19 muncul masalah dalam menentukan pemangku takhta di Cirebon. Dengan keberadaan beberapa sultan di Cirebon, bagi Kompeni hal ini merupakan kesempatan untuk melancarkan politik adu domba (divide et impera). Kebanyakan keluarga keraton dan rakyat memilih Raja Kanoman yang memiliki pribadi unggul, tetapi Kompeni memilih calon lain yang diangkat menjadi sultan di Cirebon. Sementara itu Kompeni melakukan perubahan dalam bidang pemerintahan yang berkaitan dengan administrasi wilayah dan kekuasaan elite politik pribumi (sultan dan bupati), kedudukan Sultan digeser menjadi pegawai pemerintah kolonial Hindia Belanda. Sehingga fungsi Kepala Pemerintahan digantikan oleh para Bupati yang diangkat oleh 
Gubernur Jenderal. Akibatnya rakyat tak puas dan merasa kecewa, kemudian rakyat mulai menyusun kekuatan untuk memberontak.

\section{METODE PENELITIAN}

Artikel ini berjudul Perlawanan Bagus Rangin: Perang Nasional yang Terlupakan. Untuk mendapatkan informasi mengenai objek kajian dalam judul tersebut penulis menggunakan metode historis sebagai cara untuk mempelajari peristiwa masa lampau. Metode historis adalah penyelidikan atas suatu masalah dengan mengaplikasikan jalan pemecahannya dari perspektif historis (Abdurahman, 2007, hlm. 53). Teknik penelitian yang digunakan dalam penulisan ini adalah studi literatur.

Adapun langkah-langkah dalam penelitian ini, menurut Ismaun (2005, hlm. 49-50) diantaranya adalah sebagai berikut Heuristik, yaitu pencarian dan pengumpulan sumber sejarah yang relevan. Dalam tahap ini penulis melakukan pencarian sumbersumber sejarah baik yang berupa buku-buku dan artikel. Kemudian kritik sumber, yaitu kegiatan menyeleksi atau penyaringan data untuk menyingkirkan bagian-bagian bahan sejarah yang tidak dapat dipercaya. Pada tahap ini, penulis melakukan kritik internal guna memperoleh fakta sejarah yang berkaitan dengan tema penelitian yang dikaji, sementara kritik eksternal tidak dilakukan karena dalam penelitian menggunakan sumber sekunder yaitu buku-buku dan artikel. Dalam Sjamsuddin (2007, hlm. 131) menjelaskan bahwa seorang sejarawan tidak akan menerima begitu saja apa yang tercantum dan tertulis pada sumber-sumber yang diperoleh. Dengan kata lain diperlukan adanya suatu proses seleksi dalam penentuan sumber dalam penulisan.

Interpretasi, yaitu proses penafsiran dan penyesuaian faktafakta sejarah yang diperoleh selama penelitian berlangsung dengan cara menghubungkan satu fakta dengan fakta yang lainnya sehingga didapatkan gambaran yang jelas mengenai fakta sejarah. Dan yang terakhir historiografi, yaitu proses penyusunan dan penulisan fakta sejarah yang telah diperoleh melalui berbagai macam proses baik 
interpretasi dan eksplanasi yang telah dilakukan berdasarkan hasil penelitian dan penemuannya yang kemudian disusun menjadi satu kesatuan sejarah yang utuh sehingga terbentuklah suatu penulisan sejarah.

\section{HASIL PENELITIAN DAN PEMBAHASAN}

Suatu peristiwa terjadi akibat adanya faktor-faktor tertentu, begitu pula dengan perlawanan Bagus Rangin di Keresidenan Cirebon. Rakyat Cirebon melakukan perlawanan karena adanya ketidakpuasan terhadap keadaan yang dihasilkan dari kehidupan petani sehari-hari. Secara umum terjadinya perlawanan Bagus Rangin dilatarbelakangi oleh keadaan politik dan sosial-ekonomi yang mendesak rakyat Cirebon.

Hubungan antara pihak Cirebon dengan Kompeni pada awalnya hanya sebatas pada hubungan dagang. Namun sejak VOC berdiri pada tahun 1602, kemudian mendirikan kantor dagang di Banten (1602), Jayakarta (1910), dan Jepara (1613), kantor ini juga berfungsi sebagai loji (benteng) kapal-kapal Kompeni/VOC yang sering datang ke pelabuhan Cirebon untuk bongkar muat barang dagangan. Selain itu Kompeni ada kalanya meminta bantuan raja Cirebon bila menghadapi masalah yang berkaitan dengan perdagangan melalui laut, hal itu terjadi karena raja Cirebon bersikap terbuka terhadap siapapun yang melakukan hubungan dagang dengan pihak Cirebon (Hardjasaputra dan Haris, 2011, hlm. 102)

Melalui perjanjian-perjanjian para sultan, VOC tidak hanya melancarkan kepentingan politik saja namun juga memuat adanya kepentingan ekonomi, hal tersebut dapat dilihat dari isi salah satu perjanjian yang diadakan pada tanggal 7 Januari 1681 yang menyebutkan bahwa "kompeni memiliki hak monopoli pembelian beras, lada, kayu, gula, kapas dan lain-lain serta bebas dari pajak impor-ekspor" (Hardjasaputra dan Haris, 2011, hlm. 108). Selain itu, adanya campur tangan Hindia Belanda dalam urusan kesultanan di Cirebon pun menjadi salah satu pemicu terjadinya perlawanan. 
Pada tahun 1798 Sultan gerakan sosial atapun perlawanan ini Kanoman (Sultan Anom IV) adalah karena sistem pajak yang meninggal dunia. Dengan turut ditetapkan oleh pemerintah kolonial. campurnya kompeni dalam Pemerintah kolonial melakukan menetapkan pergantian sultan, maka pembaharuan dengan menerapkan yang diangkat sebagai penggantinya sistem perpajakan. Para pejabat bukan Raja Kanoman Pangeran pemerintah baik pusat maupun daerah Suryanegara yang dicintai rakyat, keresidenan Cirebon melakukan melainkan Pangeran Surantaka, putra eksploitasi dengan memungut pajak yang lebih muda dari selir dan justru tidak disenangi rakyat, Pangeran Surianegara bersama dua orang saudaranya, yaitu Pangeran yang ilegal, terlebih lagi pajak yang diterapkan sangat tinggi.

Pajak tersebut adalah sepersepuluh dari setiap penghasilan Kabupaten dan Pangeran Lautan diusir dari keraton (Ekadjati, 1990, hlm. 99). Hal serupa diungkapkan Hardjasaputra dan Haris (2011, hlm. 128) bahwa yang seharusnya menjadi pengganti Sultan Kanoman adalah Sultan Anom IV karena ia putra tertua sekaligus putra mahkota, namun pangeran Raja Kanoman alias putra Sultan Anom IV beserta dua orang saudara kandungnya, yaitu Pangeran Kabupaten dan Pangeran Lautan justru diusir dari keraton, kemudian Pangeran Raja Kanoman dibuang ke Ambon.

Sementara pada bidang ekonomi yang menyebabkan masyarakat keresidenan Cirebon ikut serta dalam atau panen. Termasuk dalam pajak juga, pajak pasar yakni setiap orang yang berjualan harus membayar bea. Ada pula pajak perikanan yang menentukan bahwa sekian dari jumlah ikan yang ditangkap adalah hak bupati, yang dapat ditebus dengan uang (Team Penerangan Umum, 1972, hlm. 181). Penjelasan tersebut menunjukan bahwa penjabat daerah diberi wewenang untuk melakukan pungutan pajak secara legal, hal ini dimanfaatkan oleh para pejabat untuk melakukan ekspolitasi. Sehingga keadaan yang demikian menimbulkan kesengsaraan bagi masyarakat.

Kondisi tersebut menyebabkan rakyat Cirebon dan sekitarnya 
mengalami kesengsaraan karena terdapat jurang pemisah antara keadaan ideal dan realita. Hal tersebut membuat mereka merindukan akan datangnya sosok manusia yang memberikan kedamaian bagi mereka. Pengharapan akan hadirnya seorang pemimpin yang mampu memimpin dan memerintah dengan kebijakan yang mendukung rakyat.

Gerakan sosial tradisional umumnya berasal dari seseorang yang menerima peranan sebagai pemimpin agama, nabi atau juru selamat, dan diikuti oleh segolongan orang-orang yang percaya kepadanya. Gerakan ini selalu bersandar pada segi-segi ghaib dan umumnya menjelma dalam segisegi eskatologis dan milenaristis. Memang gerakan itu haruslah dipandang sebagai gerakan yang bersifat revolusioner dalam pengertian bahwa gerakan itu menghendaki munculnya suatu millennium, yaitu harapan terhadap datangnya jaman keemasan yang tidak mengenal penderitaan rakyat dan semua ketegangan serta ketidakadilan telah lenyap (Poesponegoro dan Notosusanto, 1993, hlm. 306).
Bagus Rangin sebagai simbol prophetisme atau kenabian dalam perlawanan tersebut hadir sebagai pemimpin yang kharismatik. Hal tersebut diidentifikasi dari ciri-ciri pemimpin yang kharismatik menurut Conger dan Kanungo (dalam Yulk, 2010, Th) yaitu memiliki wawasan strategis, pendirian yang kuat, keyakinan diri, perilaku yang tidak konvensional dan energi yang dinamis. Kepercayaan terlihat menjadi komponen penting dari pemimpin kharismatik, pengikut lebih mempercayai pemimpin yang kelihatan tidak terlalu termotivasi oleh kepentingan pribadi daripada oleh perhatian terhadap pengikut. Proses pengaruh utama dari teori ini adalah identifikasi pribadi, yang pengaruhnya diperoleh dari keinginan seorang pengikut untuk menyenangkan dan meniru pimpinannya. Masyarakat Jatitujuh (Bantarjati) mengamini bahwa sosok Bagus Rangin adalah seorang tokoh yang kharismatik, gagah berani, tegas, tanggung jawab dan sanggup menyatukan setiap keresahan rakyat pribumi yang terusik oleh ancaman kolonialisme. Kepemimpinan Bagus Rangin 
dianggap tulus dan benar-benar karena ingin membela rakyat yang mengalami kedzaliman oleh pemerintah kolonial, sehingga perlawanan Bagus Rangin didukung penuh oleh seluruh pengikutnya.

Bagus Rangin digambarkan Stapel (dalam Ekadjati, 1990, hlm. 102) sebagai pemimpin yang gagah berani dan sanggup menyatakan perang yang didukung oleh pengikutnya yang banyak. Bagus Rangin berguru ilmu agama kepada seorang ulama yang disebut Rama Banten atau Ama Banten. Latar belakang itulah yang membuatnya dipandang oleh masyarakat setempat sebagai pemimpin yang terhormat, disegani dan diharapkan dapat menolong masyarakat yang sedang menderita kesusahan dan kemudian membawanya kedalam kejayaan dan kemakmuran. Ekadjati lebih lanjut (1990) mengatakan bahwa Bagus Rangin adalah tokoh yang berasal dari daerah Demak Blandong, Rajagaluh yang masih wilayah Majalengka yang berada di kaki gunung Ciremai.

Sejak kecil Bagus Rangin telah belajar ke beberapa guru dan belajar ilmu thariqah. Salah satu gurunya yang mempengaruhi sikap dan tindak tanduknya adalah Rama Banten. Makna thariqah sendiri memiliki arti menahan hawa nafsu seperti melakukan puasa berpantang, meninggalkan tempat ramai untuk berkhalwat di tempat yang sunyi. Seperti di gunung-gunung, goa, hutan belantara, orang Cirebon mengenalnya dengan sebutan Mati Geni. Pernyataan ini diambil dan crosscheck proses verbal terhadap keponakan Bagus Rangin yang tertangkap Belanda yakni Bagus Manoch, ia diinterogasi mengenai sejarah bagaimana Bagus Rangin mendapatkan kesaktiannya (Amin, 2015, hlm. 170).

Kerusuhan meletus sejak awal abad ke-19 berupa gerakan perlawanan rakyat yang menentang Belanda beserta kaki tangannya. Belanda mensinyalir bahwa pecahnya kerusuhan itu sesungguhnya digerakkan oleh Pangeran Suriawijaya. Hal ini lebih dijelaskan lagi oleh S.H. Rose selaku Residen Cirebon pada waktu itu dengan mengatakan bahwa yang menyebarkan desas desus untuk membenci pemerintah Belanda ialah Raja Kanoman (Pangeran Suriawijaya) dan 
sebagian dari kaum agama yang telah memihak Kanoman harus ditangkap (Ekadjati, 1990, hlm. 100).

Saran tersebut pun dilakukan oleh pemerintah Belanda dengan menangkap Raja Kanoman beserta dua saudaranya. Namun setelah penangkapan tersebut bukanlah meredakan kerusuhan, rakyat Cirebon bahkan semakin memberontak. Ekadjati (1990, hlm. 101) menerangkan bahwa pada tahun 1805 rakyat Cirebon yang terdiri atas kurang lebih 1000 orang mengadakan perjalanan (long march) ke Batavia guna menyampaikan tuntutan supaya Raja Kanoman dibebaskan dan dinobatkan sebagai sultan di Cirebon.

Perlawanan Bagus Rangin terhadap kolonial dan kaki tangannya pertama kali terjadi pada tahun 1806 yaitu berdasarkan pemberitahuan Van Lewick dalam resolusi tanggal 25 Februari 1806 tentang adanya gerakan yang melawan pemerintah kolonial (Ekadjati, 2014, hlm. 64). Gerakan perlawanan Bagus Rangin terhadap pemerintahan kolonial tersebut memperoleh dukungan dari rakyat Cirebon terutama dari kalangan petani, para ulama dan para santri. Sasaran pertama gerakan perlawanan rakyat Cirebon adalah orang-orang Cina karena mereka dianggap secara langsung memeras rakyat. Banyak orang Cina yang dibunuh atau diusir dari daerah Cirebon antara lain di Palimanan, Lohbener dan Dermayu (Lubis dkk, 2011, hlm. 456). Keterangan tersebut juga ditegaskan dalam Dasuki (1977, hlm. 199) yang berdasarkan naskah dermayu bahwa “...kurang lebih 1000 orang rakyat dari berbagai desa di sekeliling Bantarjati dan Jatitujuh yang akan beramai-ramai menyerang kota Indramayu".

Pada tahun berikutnya wilayah Nusantara berada dibawah kekuasaan Inggris, yang diwakili oleh Letnan Gubernur Jenderal T.S. Raffles. Bagus Rangin beranggapan pemerintahan Raffles pasti tidak akan berbeda dengan penjajah sebelumnya. Maka ia pun tetap mengumpulkan kekuatan untuk meneruskan perjuangannya. Dalam rangka mematangkan persiapan melawan kembali kolonial, Bagus Rangin melakukan penggemblengan khusus terhadap pemimpin pasukan dan pengikutnya. Menurut keterangan penduduk 
Jatitujuh saat itu (dalam Ekadjati, beban rakyat berupa kerja paksa. 1990, hlm. 109) waktu Sasaran gerakannya sendiri bukan lagi penggemblengan dilakukan setelah merusak dan menghancurkan, akan sembahyang Jum'at di masjid tetapi juga mendirikan negara sendiri. Jatitujuh. Mereka berpakaian serba Melalui sarana negara dan putih sebagai tanda ikhlas, rela pemerintahan yang akan dibentuk berkorban, baik harta, jiwa maupun itulah tujuan gerakan itu dapat raga demi tanah air, bangsa dan tercapai. Dalam rencana ini Bagus agama. Penggemblengan dan Rangin akan diangkat sebagai raja. komando terutama diberikan oleh Kerajaannya akan dinamakan negara Bagus Rangin. Sementara senjata yang mereka gunakan masih bersifat tradisional yaitu terdiri dari; keris, tombak, cangak, gada, panah dan wareng. Pada saat itu Bagus Rangin berhasil menghimpun dan membina kembali para pengikutnya. Pengaruh Bagus Rangin di kalangan para pengikutnya dan masyarakat setempat pada umumnya sangat besar. Sehingga dianggap sebagai titisan Ratu Adil yang akan membebaskan rakyat dari kedzaliman, membawa keadilan dan kemakmuran bagi rakyat.

\section{Perlawanan Bagus Rangin}

tidak lagi dimaksudkan untuk melakukan peperangan, melainkan untuk membela rakyat yang sedang sengsara akibat masalah yang bertalian dengan penanaman padi dan untuk berikhtiar guna meringankan Panca Tengah dan ibukotanya di Bantarjati (Ekadjati, 1990, hlm. 109).

Setelah pertempuran di lapangan Jawura (alun-alun Bantarjati) terjadi, kekalahan ada di pihak Bagus Rangin karena pada saat itu pihak kolonial memiliki persenjataan modern dan jumlah pasukannya lebih banyak sehingga pasukan Bagus Rangin terpaksa harus mundur. Namun hal tersebut tidak menyulutkan semangat perlawanan Bagus Rangin. Usahausaha Penumpasan perlawanan Bagus Rangin dilakukan oleh pemerintah Hindia Belanda terhalang oleh penggantian pemerintahan kolonial dari tangan Belanda ke tangan Inggris (1811). Hal tersebut merupakan kesempatan Bagus Rangin dan pengikutnya untuk melakukan konsolidasi dan menyiapkan kekuatan 
untuk melakukan perlawanan kembali. Sampai terjadi lagi perang besar yang melibatkan banyak pasukan dari berbagai wilayah sekitar keresidenan Cirebon.

Pertempuran pun terjadi lagi di medan tempur Bantarjati pada tanggal 16 sampai dengan 29 Februari 1812. Pertempuran berjalan sengit, namun tak lama kemudian pengikut Bagus Rangin dapat dipukul dan sebagian mundur secara teratur, kemudian melarikan diri, termasuk Bagus Rangin. dalam pertempuran tersebut kerugian dari pihak Bagus Rangin adalah 87 orang prajurit tewas, 227 orang dan dua orang pemimpinnya tertangkap dan dapat dirampas sebanyak 23 pucuk senapan, 19 buah tombak, 27 buah pedang atau bedog dan tiga buah keris. Selain itu terampas pula payung kebesaran Bagus Rangin dan perlengkapan wayang serta 776 orang keluarga kaum perlawanan yang terdiri atas wanita dan anak-anak ditahan (Ekadjati, 1990, hlm. 111-112).

Setelah pertempuran selesai, pemerintah kolonial melakukan operasi militer guna menumpas pasukan-pasukan yang melarikan diri ke desa-desa. Operasi militer tersebut berhasil menangkap pemimpin perlawanan yaitu Bagus Rangin di Panongan, Majalengka pada tanggal 27 Juni 1812. Berdasarkan keterangan Ekadjati (1990, hlm. 112) informasi tersebut diperoleh dari sumber pemerintah kolonial yang dicatat pada waktu Bagus Rangin tertangkap (tanggal 27 Juni 1812) dan kemudian diinterogasi (tanggal 22 Juli 1812).

Dengan tertangkapnya Bagus Rangin oleh kolonial, maka berakhir pula perlawanan Bagus Rangin. di keresidenan Cirebon. Belum ada sumber yang menerangkan apakah Bagus Rangin dihukum mati atau tidak. Namun dalam seminar nasional "Pengusulan Bagus rangin sebagai Pahlawan Nasional" yang diadakan di Majalengka pada tanggal 5 September 2015 yang dihadiri oleh beberapa narasumber ahli sejarah, seperti $\mathrm{R}$. Achmad Opan Safari Hasyim, peneliti asal Cirebon menyebutkan bahwa sumber-sumber lokal menyatakan bahwa Bagus Rangin selalu menang dalam peperangan dan tidak pernah tertangkap apalagi dibunuh, sumbersumber lokal itu hanya menyatakan bahwa Bagus Rangin 'menghilang'. 
Nina Lubis, yang juga seorang peneliti sejarah memberikan komentar, bahwa menurutnya fakta dan data sejarah menyebutkan bahwa Bagus Rangin ditangkap oleh pemerintah Hindia Belanda, hanya orang dulu tidak tega menyebutkan peristiwa mengenaskan tersebut, oleh karena itu didalam naskah atau cerita tuutr mereka hanya menuliskan bahwa Bagus Rangin 'menghilang', 'ngahiang', atau 'moksa'. Lebih lanjut dalam karyanya Sejarah Jawa Barat Jilid 1 Nina Lubis mengemukakan bahwa "operasi militer pasukan pemerintah kolonial terus dilanjutkan ke daerah-daerah pedesaan dan akhirnya berhasil menangkap Bagus Rangin di Panongan pada tanggal 27 Juni 1812” (2011, hlm. 467).

Berakhirnya perlawanan Bagus Rangin tidak menyulutkan semangat rakyat untuk melawan pemerintahan kolonial. Pada tahuntahun berikutnya terjadi lagi pemberontakan yang dimaksudkan untuk melawan pemerintah kolonial yang berarti meneruskan cita-cita Bagus Rangin. Buktinya pada tanggal 8 Desember 1816 tersiar berita bahwa orang-orang penduduk Karawang,
Ciasem, dan Pamanukan yang jumlahnya sekitar 2.500 orang lakilaki bersenjata lengkap bermaksud untuk berontak melawan pemerintah, mereka dipimpin pemuda berumur 16 tahun bernama Bagus Jabin yang merupakan putra Bagus Sanda, keponakan Bagus Rangin (Ekadjati, 1990, hlm. 112). Keterangan tersebut menunjukan bahwa perlawanan yang dipimpin oleh Bagus Rangin telah mampu menggerakkan dan mengilhami perlawanan-perlawanan selanjutnya.

Dampak perlawanan Bagus Rangin juga cukup berpengaruh terhadap pemerintah kolonial yaitu menyebabkan kerugian secara materi. Untuk keperluan menindas perlawanan rakyat yang tak kunjung berhenti itu, pemerintah perlu uang, maka banyaklah tanah yang dijual kepada swasta baik perusahaan maupun perorangan (Dasuki, 1977, hlm. 209). Hal tersebut wajar mengingat begitu besarnya perlawanan yang dilakukan Bagus Rangin hingga melibatkan ribuan pasukan dari berbagai daerah sehingga penghasilan pemerintah kolonial tidak cukup untuk membiayai perang. 
SIMPULAN

Perlawanan Bagus Rangin yang terjadi di Bantarjati, keresidenan Cirebon pada tahun 1806-1812 merupakan sebuah gerakan sosial yang dilakukan oleh rakyat Cirebon dalam menentang pemerintahan kolonial. Perlawanan yang dipimpin oleh Bagus Rangin tersebut dilatarbelakangi oleh adanya faktor politik dan sosial-ekonomi. Dominasi kolonial dalam bidang politik menimbulkan keresahan bagi masyarakat Cirebon, campur tangan kolonial dalam pengangkatan Pangeran Surantaka menjadi sultan sepeninggalnya Sultan Kanoman menyebabkan kekecewaan bagi rakyat, karena masyarakat menilai bahwa Raja Kanoman dianggap lebih pantas untuk menjadi pemimpin karena selalu membela rakyat Cirebon. Sementara itu, dalam bidang ekonomi pemerintah kolonial melakukan pembaharuan dengan menerapkan sistem perpajakan. Dengan sistem ini masyarakat Cirebon dibebani berbagai macam pajak diantaranya pajak kepala, pajak tanah, pajak jembatan dan lain-lain.
Perlawanan Bagus Rangin dipicu oleh adanya penangkapan yang dilakukan pemerintah kolonial terhadap Raja Kanoman. Tindakan tersebut menimbulkan keresahan bagi masyarakat, lalu rakyat Cirebon mendesak Bagus Rangin yang merupakan pimpinan kebagusan Jatitujuh pada masa itu untuk segera melakukan perlawanan, sehingga terjadilah peperangan pada tahun 1806 yang didukung oleh beberapa daerah (Cirebon, Majalengka, Indramayu, Kuningan dan Sumedang). Perlawanan dipimpin oleh Bagus Rangin yang pada saat itu menjabat sebagai pemimpin kebagusan Jatitujuh (Bantarjati). Sebagai simbol prophetisme atau kenabian dalam perlawanan, Bagus Rangin dipandang sebagai pemimpin yang kharismatik dikarenakan memiliki ilmu agama yang tinggi dan selalu membela rakyat kecil, sehingga masyarakat mengenal Bagus Rangin sebagai pemimpin terhormat, disegani dan diharapkan dapat menolong masyarakat yang sedang menderita. Hal tersebut wajar terjadi karena sifat dan sikap yang dimiliki Bagus Rangin memenuhi 
kriteria seorang pemimpin yang berkharisma.

\section{Perlawanan Bagus Rangin}

yang berakhir pada tahun 1812 merupakan peristiwa yang cukup penting bagi kehidupan masyarakat Cirebon. Hal tersebut dapat dilihat dari dampak yang ditimbulkan dari perlawanan tersebut. Meskipun perlawanan Bagus Rangin mengalami kegagalan yaitu dengan tertangkapnya pemimpin perlawanan, namun dampak sosial yang ditimbulkan dari perlawanan tersebut cukup berpengaruh terhadap masyarakat Cirebon. Setelah terjadinya perlawanan Bagus Rangin, selanjutnya muncul lagi perlawanan di Cirebon yang meneruskan perjuangan Bagus Rangin dalam usaha menghapuskan kolonialisme di Cirebon. Hal tersebut menandakan bahwa perjuangan Bagus Rangin telah memotivasi generasi selanjutnya untuk tetap melawan kolonialisme sekaligus melanjutkan cita-cita Bagus Rangin.

\section{DAFTAR PUSTAKA}

Abdurahman, D. (2007). Metodologi Penelitian Sejarah. Jogjakarta: Ar-ruzz Media.

Amin, Zamzami. (1013). Baban Kana: "Ati Bagus Allah Kabul"; Sejarah Pesantren Babakan Ciwaringin dan Perang Nasional Kedongdong 18021919. Bandung: Humaniora.

Dasuki, dkk. (1977). Sejarah Indramayu. Indramayu: Pemerintah Kabupaten Indramayu.

Ekadjati, Edi S. (1990). Sejarah Perlawanan Terhadap Imperialisme dan Kolonialisme di Daerah Jawa Barat. Jakarta: Perpustakaan Nasional.

Ekadjati. (2014). Dari Pentas Sejarah Sunda: Sangkuriang hingga Juanda. Bandung: PT. Kiblat Buku Utama.

Hardjasaputra, A. dan Haris, T. (2011). Cirebon dalam Lima Zaman: Abad ke-15 hingga Pertengahan Abad ke-20. Bandung: Dinas Pariwisata dan Budaya Provinsi Jawa Barat.

Ismaun. (2005). Sejarah Sebagai Ilmu. Bandung: Historia Utama Press.

Lubis, dkk. (2011). Sejarah Provinsi Jawa Barat Jilid 1. Bandung: Pemerintah Provinsi Jawa Barat.

Poesponegoro dan Notosusanto. (1933). Sejarah Nasional Indonesia IV. Jakarta: Balai Pustaka. 


\section{FACTUM}

Volume 6, Nomor 1, April 2017

Sjamsuddin, Helius. (2007). Metodologi Sejarah. Yogyakarta; Ombak.

Team Penerangan Umum. (1972). Sedjarah Djawa-Barat Suatu
Tanggapan. Pemerintah daerah Djawa Barat.

Yulk, Gary. (2010). Kepemimpinan Dalam Organisasi Edisi Kelima. Jakarta: PT. Indeks. 